\title{
Origin Recognition Complex Subunit 4
}

National Cancer Institute

\section{Source}

National Cancer Institute. Origin Recognition Complex Subunit 4. NCI Thesaurus. Code C34016.

Orig in recognition complex subunit 4 (436 aa, $\sim 50 \mathrm{kDa}$ ) is encoded by the human ORC4 gene. This protein is involved in the replication of DNA. 